\title{
A Post-colonial Study of the Short Story "Araby" (1914) by James Joyce
}

\section{Pedram Maniee}

\author{
M.A Student of English Literature, \\ School of Letters and Human Sciences, Shahid Beheshti University, Tehran \\ Email: p.maniee@mail.sbu.ac.ir
}

\section{Shahriyar Mansouri}

Assistant Professor of Modern English and Irish Literature, School of Letters and Human Sciences, Shahid Beheshti University, Tehran Email: s_mansouri@sbu.ac.ir

Doi:10.5901/mjss.2017.v8n2p201

\section{Abstract}

\begin{abstract}
The short story of "Araby" by James Joyce was published in 1914 in Dubliners which is a collection of fifteen short stories set in the Dublin city of Northern Ireland. "Araby" is one of those short stories in which traces of the colonization of Ireland by the Great Britain in the nineteenth century can be found. Since the context of the short story is set in Dublin, analyzing it in light of post-colonial theory has made it a special case. Because despite the majority of literary works which are analyzed in light of post-colonial theory and in which the contrast between east and west geographically is quite visible, in "Araby" this contrast is not clear-cut and the culture of two neighbor countries are so close and as a consequent so difficult to claim cultural and religious colonization by a neighbor country. This essay investigates the way Joyce has portrayed the cultural, political, economic and social domination of Britain over Ireland, specifically Dublin. The essay also explores the context where Joyce had the motivation to write Dubliners and shows the fundamental principles of post-colonialism such as language, the notion of superior/inferior, cultural polyvalency, Self/Other and the critical tenets of Homi K. Bhabha including mimicry, liminality or hybridity and finds these tenets within this short story. The essay also investigates the way James Joyce has employed symbolism in order to portray his reaction to the domination of Britain over Ireland.
\end{abstract}

Keywords: Post-colonial Literature, James Joyce, Dubliners, "Araby", Homi K. Bhabha

"They think they have pacified Ireland. They think that they have purchased half of us and intimidated the other half. They think they have foreseen everything, think that they provided against everything; but the fools, the fools, the fools! - they have left us our Fenian dead, and while Ireland holds these graves, Ireland unfree shall never be at peace". -

Padraig Pearse, in oration at funeral in Glasnevin of Fenian Jeremiah O'Donovan Rossa, August 1, 1915.

\section{Introduction}

The short story that this essay has selected to investigate based on post-colonial theory and critical approach is one of the fifteen short stories in a collection entitled as Dubliners written over a three-year period (1904-07). Having in mind ten short stories to be included in this series, Joyce later added two more stories including "Araby" and "Grace". Dubliners is an analysis of the Irish middle and lower classes. Joyce selected Dublin both as the geographical setting as well as giving it a psychological status within this collection. Since the collection seemed critical to the Irish living of the time, Joyce had difficulty in finding a publisher to publish it. According to a letter to Grand Richards written in May 1906, Joyce stated the overall design of his work:

I have tried to present it [Dubliners] to the indifferent public under four of its aspects: childhood, adolescence, maturity and public life. The stories are arranged in this order. I have written it for the most part in a style of scrupulous meanness and with the conviction that he is a very bold man who dares to alter in the presentment, still more to deform, whatever he has seen and heard

"Araby" as well as "The Sisters" and "An Encounter" forms the first phase of Dubliners that is childhood and "Araby" is the third and the last of this trio. Joyce's style is lucid, direct and realistic in Dubliners and in it he tries to mirror Dublin's atmosphere in a way that is dull, dreary, depressing and gloomy. 
Based on an Irish history of nationalism, this essay investigates "Araby" from the postcolonial perspective. To this end, the methodological framework is primarily based on post-colonial binary oppositions such as the emergence of superior/inferior, Self/Other, as well as supranational concepts such as language and religion. Moreover, to maintain a relevant critical approach critical theories of Homi K. Bhabha such as mimicry, hybridity or liminality will be discussed and revisted. "Araby" is a special case since the opposition between the East and the West is not that much evident to claim at least cultural domination by a neighbor country although a British influence should not be overlooked. The question is how a government can culturally colonize another nation while sharing maritime borders. This latter, will be addressed by indulging in cultural criticism.

In part one this essay explores the context where Joyce felt the responsibility to write from the part of his people in particular those living in Dublin. In the second part, which is Discussion, the tenets of post-colonial theory which the writer found applicable to the short story are claimed and then proved with reference to the text of the short story. The third part investigates the way Joyce employed symbolism in portraying the domination of his nation by the British Empire with reference to certain images and sentences.

\section{Joyce's Task of Writing in Dublin and the Context of Publication of His Dubliners}

The meaning of politics is nothing but hegemony and superiority of a group of people over other groups of people and this paradigm is performed in many different ways. This is a problem in which many countries and regimes have been involved. If this is extended to other issues and problems there would appear several implications. One of these implications would be the conflicts and contradictions between people and government and even between the structures of the government itself.

Reasons for emerging fights in international domain lead to differing discussions, views and approaches. One of the principal reasons for emerging fights is found within the power structures and affinities in international relations, another principal reason for the emergence of conflicts and fights is due to political, economic, psychological and sociological factors within the governments. Also the capitalistic governments' efforts to establish foreign markets and their efforts to obtain precious raw materials can be another reason for the need for hegemony, war and domination over other lands. Above all the trick to solve the inner problems within a power structure by contrasting "themselves" to "others" can lead to conciliation and accordance among men of differing political views. These general views are influential in knowing the reason for the conflicts between Northern Ireland and England (the Great Britain).

The principal reasons for local conflicts within Northern Ireland are both political and religious. The political motivation of the conflict, which in the nineteenth century had the strong moral and material support from the part of influential people of Ireland descent living in the United States, was to put centuries of British colonization over all land of Ireland to an end. The religious reason of the conflict was the fact that the majority of the native Irish people were catholic and for this specific reason the Irish fight for independence and their fight against the colonization of the Great Britain were synonymous with their fight against English Protestant church and its hegemony over the Catholic Irish people.

"Araby" was published by the London firm of Grant Richards in 1914. Some of the major historical and political events occurring in Ireland immediately before and after the writing and publication of the short story were: the beginning of Irish revolution against the British rule in 1912; the Irish Home Rule Bill which granted an independent parliament to Ireland which was passed, although its enactment was delayed until 1920; The Easter Rebellion which broke out in Dublin in which Irish nationalist forces took control of the city before they were forced to surrender by British troops (April 24- April 29); the Irish War of Independence between Irish nationalists and British forces during 1919- 1921; also in the year 1920 the government of Ireland established six of the nine counties of Ulster as the province of Northern Ireland and granted independent parliaments to both Ireland and Northern Ireland; in 1921 Anglo-lrish Treaty was signed which ended the Irish War of Independence and granted limited freedom to Ireland in December 6; finally in 1922 the Irish Free State is established and ended the Irish Revolution.

As it is evident, James Joyce was writing Dubliners within this highly tumultuous context of conflict. While he was a teenager, he underwent a religious crisis and abandoned his Catholic faith. Although he felt a somewhat alienation from his Catholic abandonment, he always respected the knowledge he received from the Jesuits. Also Scholasticism had an influential impact on his thinking and motivation. Joyce in fact articulated powerful criticism of the sort of Catholicism running throughout his country. He also criticized Irish Nationalism, Celtic revival and also Irish family life that later on turned into his dominant themes in his later fictions. The oppressive religious, economic, cultural and political forces on the lives of the middle class and lower middle class Irish people in particular those inhabitants of Dublin provided the material for Joyce to realistically reflect Dubliners as paralyzed people.

Since the short stories of Dubliners are written within the context of cultural upheaval, it is evident that Joyce and 
his family had difficulty to make themselves adaptable to the radically different environment of life within Dublin and as mentioned, these struggles have been portrayed in his short stories.

\section{Discussion}

As a critical reading approach in literary and cultural studies, post-colonialism has gained currency since the publication of Edward Said's influential critique of the Western constructions in his book Orientalism. The book investigates how the formal study of the Orient supported certain ways of thinking which in turn led to continuation of colonial power. Another yet influential critical thinker of post-colonialism was Homi K. Bhabha and his key ideas including the discourse of stereotypes and mimicry among others were influential in shaping this new critical approach.

The post-colonial critical approach emphasizes a range of issues including race, centrality, mimicry, sexuality, the Self/Other, liminality, hybridity, language and superior/inferior. As it is mentioned, Homi K. Bhabha's approach in postcolonialism is involved with such concepts as mimicry, hybridity or liminality. In analyzing "Araby" based on Bhabha's approach, these two concepts have been employed within this essay. Apart from his approach, the essay explored the notion of language and superior/inferior concept based on which "Araby" has been analyzed post-colonially in this essay.

\subsection{Postcolonial Notion of Mimicry}

According to Bhabha, the three notions of mimicry, hybridity and liminality are connected to each other and it is not possible to investigate them separately. The colonizing discourse always wants the colonized to be like the colonizer but by no means identical. If they were exactly identical then how the operation of the colonial rule could be justified? The colonizer simultaneously wants the colonized to be like them but at the same time it does not want itself to be regarded the same as the colonized. The colonizer believes there is a split between the superior and inferior and this is why a group of people can dominate other groups of people not only economically and politically, but also can bring them under their cultural domination, through missionary, altering their academic language, to mention just a few possibilities. According to Bhabha:

Colonial mimicry is the desire for a reformed, recognizable Other, as a subject of difference that is almost the same, but not quite. Which is to say, that the discourse of mimicry is constructed around an ambivalence; in order to be effective, mimicry must continually produce its slippage, its excess, its difference. (The Location of Culture: 86)

Considering these two opposite forces of the colonizer and the colonized, this essay focuses on the type of colonization that was running through the British Empire rather than through other colonizing Empires. The fact is that the two great colonizing countries of France and Britain had relatively different approaches: the British one was pursuing difference while the French colonization focused on the sameness.

Therefore the colonizer which supposes itself as the superior force, employs mimicry as a strategy for maintaining the dominance over the colonized as "the Other" or the stereotype in order to justify its identity and authority. On the other hand, the colonized also makes use of mimicry in order to destabilize this identity and power. As a result, the Other (colonized) by means of mimicry impairs the strategy of the self (colonizer) which has the "assumed priority" over it. The colonized has the capacity to make up a new identity for itself.

In "Araby" the bazaar has been described as a splendid place for the narrator to visit it and despite the narrator's enthusiasm, his uncle wants him not to go there. Just imagining him as a knight who wants to carry the Holy Grail and buy a gift to his fair lady, the narrator actually imitates the way colonizers want to explore the East (here the Bazaar). When he passes by train and passes through the river he reaches the bazaar and is disappointed by the atmosphere and the epiphany happens there. The narrator then receives a new identity which is quite different from the sort of identity he had in the beginning of the story: "Gazing up into the darkness I saw myself as a creature driven and derided by vanity; and my eyes burned with anguish and anger" (ending sentence of the story). Perhaps this new identity is the narrator's forced compatibility to Dublin's dull surroundings.

\subsection{Postcolonial Notion of Hybridity}

Another significant theoretical concept within postcolonial theory is hybridity which is also known as liminality. In discourse analysis this concept had been employed for the first time by Mikhail Bakhtin in his The Dialogic Imagination. According to Bakhtin, hybridization is a "mixture of two social languages within the limits of a single utterance, an 
encounter within the arena of an utterance, between two different linguistic consciousness, separated from one another by an epoch, by social differentiation or by some other factor" (The Dialogic, p 258.).

Homi K. Bhabha employs this notion in order to investigate the relationship between the colonizer and the colonized and shows that these two have double identities. Bhabha does not believe in the superiority of the colonizer and asserts that culturally these two have mutual impact on each other. In The Location of Culture he asserts that: "Hybridity is the name of this displacement of value from symbol to sign that causes the dominant discourse to split along the axis of its power to be representative, authoritative. Hybridity represents that ambivalent 'turn' of the discriminated subject into the terrifying, exorbitant object of paranoid classification - a disturbing questioning of the images and presences of authority" (112).

The colonizer does not have absolute authority and identity and although tries to reject the culture of the colonized, it is under its influence. Therefore these two forces are being shaped and reshaped by each other.

Throughout the story we realize that the boy cannot understand Mangan's sister fully with whom he had little communication. In the moment he had the opportunity to communicate with her, he invites her to the bazaar however she rejects since she had to go to the "Retreat": "She could not go, she said, because there would be a retreat that week in her convent" (ninth paragraph). Retreat which was popularized in Roman Catholicism by the Jesuits is a period of seclusion for meditating, getting advice, praying and discovering ways of improving moral life. Also in the fifth paragraph of "Araby" the narrator says: "Her name sprang to my lips at moments in strange prayers and praises which I myself did not understand. My eyes were often full of tears (I could not tell why) and at times a flood from my heart seemed to pour itself out into my bosom". These show how the Irish life is so much intertwined with its dominant religion which was Roman Catholicism. The narrator refers to prayers and praises as "strange" and he mentions that I cry and "I don't understand why". The narrator does not know what his belongings are. The Irish people, for which the narrator is a symbol, underwent an identity crisis because of the hybridity that was prevalent throughout their culture as a result of the British political domination over Ireland. The bazaar and the presence of the woman and several other men as well as their arguments indicate the direct struggle of the colonizer and the colonized. The bazaar stands for the colonized and the woman and the men with English accent stand for the colonizers who seem to have conflict with each other. As a result of lack of self-recognition and as a result of rejecting the identity of the Other, the colonized experiences a crisis that is shown in the tone and content of their dialogue.

\subsection{Language in Post-colonialism}

Language as one of the instances of nationality and culture, has a direct relationship to social changes and is in parallel with workings of power structures. The colonizer, overtly and covertly imposes its language on the colonized nation in order to extend its influence within the targeted culture. Therefore language can be regarded as the principal element in shaping postcolonial theory. Language of any nation has inseparable affinity with its culture and language is the verbal manifestation of a given culture. According to Paulin "The history of a language is often a story of possession and dispossession, territorial struggle and the establishment and imposition of a culture." (Paulin, 1983). Removing the mother tongue is one the most brutal tool used by the colonizing power for establishing their dominance.

Irish language is a special case since it underwent major changes throughout its history. Irish language has always been attacked and the first one was during the twelfth century when the Anglo-Norman Knights came into Ireland. The second major event was the imposition of the Penal Laws, a series of laws according to which Irish Roman Catholics and Protestant dissenters had to accept the reformed dominations defined by the English state. Another law of Penal Laws was forbidding the use of Irish language. As a result, anyone who wanted to pursue education had to do so by English language and his/her Irish tongue caused to become marginalized. Inauguration of the National School system further established English as the required medium for educating is schools. The final event was the great Famine running through Ireland in 1846 which eradicated one third of the population of the country. As a consequence, the Irish people further felt a need to compensate for their economic loss and had no choice but employing English in order to reconstruct economically their nation.

Samuel Beckett, Oscar Wilde and James Joyce among others were figures who wrote in the language of the colonizer and introduced a new trend in English Literature. The production of new literature is somehow related to the notion of hybridity mentioned earlier in this essay. A new literature produced a new identity which was the result of the writers' entrapment within two opposing forces of the colonizer and colonized. In addition to this emerging new identity, the use of language of the colonizer in literature, helps the writers to destabilize and undermine the power structures and authority of the colonizer.

This hybridity is evident in the case of "Araby". The infatuated narrator with imagining himself as a knight on a 
quest for bringing the Holy Grail, reaches the bazaar and on his course the reader can trace signs of disillusionments. This reaches its peak when the narrator hears the English quarrel among the women and the men which results in the final sentence which is at the same time the climax of the story and is where the epiphany occurs. Joyce indirectly criticizes the way (imposition of English language) the colonizer has made the "splendid" bazaar (Ireland) such a dull and depressing land.

Although Joyce is writing in English, there exist references in the story that indicates Joyce's celebration of Dublin's native culture and language. Such cases are to be found in the songs and ballads by the singers and their traditional Irish tunes. Ballads of come-all-ye's is about the Irish history and politics: "... the nasal chanting of street-singers, who sang a come-all-you about O'Donovan Rossa, or a ballad about the troubles in our native land ..." (fifth paragraph). Apart from linguistic significance, these ballads have political overtones. For instance O'Donovan Rossa (1831-1915) was a revolutionary figure and a prominent member of the Irish Republican Brotherhood who worked to overthrow the British Empire within Ireland. Deliberately a quotation from O'Donovan Rossa is mentioned at the beginning of this essay to further indicate the fact that Joyce meant to criticize the domination of the British rule over Ireland (at least one of his purposes) by means of writing this short story.

\subsection{Superior/Inferior Notions in Post-colonialism}

"Always with reference to the superiority of an expanding Europe, colonized peoples were represented as lesser, less human, less civilized, as child or savage, wild man, animal, or headless mass" (Colonial \& Post-colonial Literature, Elleke Boehmer). The superior/inferior notion is perhaps one of the most evident and fundamental notion of Post-Colonial theory. In his most influential book Orientalism (1978) which is about Occident's discourse about The Orient, Said argues that the academic study of the Orient was created as a result of taking several other cultures into account as "nonWestern" ones. Orientalism is rooted in this belief that there is a "radical" distinction between the Occident and the Orient and that everything is an evidence to support this fundamental assumption. The only thing that the colonial discourse wants is the domination of the colonized. But in what way this domination is obtained? The only way to establish this domination is proving that the colonized is different from and subsequently inferior to the colonizer. Due to the superiority of the colonizing powers' economy and politics, they too believe in their superiority of culture and manner and as a consequence they regard themselves as absolutely superior. In order to establish this superiority they exert any possible forces, including linguistic, political, cultural and economic.

As mentioned earlier, Joyce was writing within this context in which everyone living in Dublin had the understanding of the notion of their cultural, religious and political superiority and inferiority.

The notion of superiority/inferiority of post-colonialism can be traced within "Araby". Perhaps the single most evident sentence from the story which proves the existence of this notion and the claim for reading the story from a postcolonial perspective is: "I did not know whether I would ever speak to her or not or, if I spoke to her, how I could tell her of my confused adoration. But my body was like a harp and her words and gestures were like fingers running upon the wires" (fifth paragraph"). This sentence has been told by the narrator and by "her" he means Mangan's sister. "Harp", as a musical instrument to which the narrator has been compared, can be regarded as Ireland in general. Throughout the story, Mangan's sister has domination over the boy. In other way we can say that at least the boy has no control over her. Mangan's sister participates in the Retreat (explained above) and therefore she can be regarded as the symbol of Roman Catholicism and as the one who controls Ireland: the colonizer. The narrator who is reduced to a musical instrument is the colonized Ireland under the domination of the colonizer: A colonized nation (harp) whose wires are played by the colonizer.

Also the narrator feels inferior and disillusioned in the bazaar when faced with the English young woman with whom he had conversation and then he "turned away slowly and walked down the middle of the bazaar ...".

\section{Post-colonial Reading of Araby's Images}

This part of the essay explores "Araby" in terms of its symbols and images. "Araby" is one of the richest stories of Dubliners in symbolism. Short story by nature has compactness in comparison to novel. As a reader of short story, therefore, one should be conscious of the images in the text. From the beginning to the end of the short story there can be found several images which could be analyzed in a way that further support the arguments of the present essay. These images have sexual, political, economic and cultural overtones which are investigated.

Before going through the images and symbols, it is worth mentioning that "Araby" which is the title story, refers to the Grand Oriental Fete which was running in Dublin from the fourteenth to nineteenth of May 1894 and Joyce and his 
relatives were living there from 1854 to 1896 . The following is a song which was chanting during the fair and shows people's views on the Orient:

I'll sing thee songs of Araby

\author{
And tales of fair Cashmere, \\ Wild tales to cheat thee of a sigh \\ Or charm thee to a tear. \\ And dreams of delight shall on thee break \\ And rainbow visions rise, \\ And all my soul shall strive to wake \\ Sweet wonder in thine eyes... \\ And all my soul shall strive to wake \\ Sweet wonder in thine eyes. \\ Through those twin lakes where wonder wakes \\ My raptured song shall sink \\ And, as the diver dives for pearls, \\ Bring tears, bright tears, to their brink. \\ And dreams of delight shall on thee break \\ And rainbow visions rise, \\ And all my soul shall strive to wake \\ Sweet wonder in thine eyes... \\ And all my soul shall strive to wake \\ Sweet wonder in thine eyes.
}

(This song is based on Lalla-Rookh by Thomas Moore which is an oriental romance)

As it is evident from the content of the song, peoples' view on the Orient is the same as the view of the narrator of the story towards the "splendid" bazaar.

"Araby" is the unfulfilled quest from the part of the narrator of the story for beauty which the narrator does amidst the numb and dark atmosphere of Dublin's scene in order to gain the chalice ("I imagined that I bore my chalice safely through a throng of foes." Fifth paragraph"). This can be regarded as a parallel to romance that was popular from nineteenth century and in which there was a knight/knights like those of the stories of King Arthur, who searched for the Holy Grail in a mysterious guarded castle. In this case, this mysterious castle has been a bazaar called "Araby", also the title story. The bazaar is the Orient and the colonized object where the colonizer is interested to have dominance over it.

The story of "Araby" is unique in the sense that it contains almost all themes of Dubliners and this essay has drawn out those related to nation, identity and colonialism. As we read the story from the beginning, we are encountered with the atmosphere of Dublin as a dull and depressing place. This atmosphere is clearly visible from the beginning words of the story. Perhaps the climax of this dark atmosphere can be found it the third paragraph:

When the short days of winter came dusk fell before we had well eaten our dinners. When we met in the street the houses had grown sombre. The space of sky above us was the colour of ever-changing violet and towards it the lamps of the street lifted their feeble lanterns. The cold air stung us and we played till our bodies glowed. Our shouts echoed in the silent street. The career of our play brought us through the dark muddy lanes behind the houses, where we ran the gantlet of the rough tribes from the cottages, to the back doors of the dark dripping gardens where odours arose from the ashpits, to the dark odorous stables where a coachman smoothed and combed the horse or shook...

Throughout the story, the reader through many images (blind, muddy, dark, ashpits, etc.) can easily notice this dark and depressing atmosphere. This atmosphere precedes the epiphany, which symbolize the sort of blindness the narrator experiences at the beginning of the story.

On the other hand, the story describes the bazaar as a splendid place ("It would be a splendid bazaar; she said she would love to go" Seventh paragraph). A place which not only is closing but also a place where small boys aren't welcomed and a place which the narrator is enthusiastic for seeing it however his uncle who has no interest in the bazaar, tries to prevent the boy from going to visit there.

At the beginning of the story there can be seen the image of the Garden of Eden beneath which there is a rusty bicycle. At the second instance (splendid bazaar), where the narrator laboriously tries to reach there we can anticipate the dullness and dreariness of the assumed splendid bazaar ("I took my seat in a third-class carriage of a deserted train" ... "In a few minutes the train drew up beside an improvised wooden platform") and when he reaches there he sees 
closing down of the bazaar and notices the English accent through the conversation among a woman and two men. The English accent, being the symbol for the presence of the colonizing power, makes the "splendid" bazaar (Ireland) a dull place. The first instance which is at the beginning of the story is their house which formerly was the house for a dead priest. The dead priest represents the deadening status of the dominant Roman Catholicism within Ireland. These contradictory images within the story strengthen the image of the domination and prevalence of British culture and government across Dublin: (the English accent of the woman in the bazaar, Roman Catholic Church and the deadened atmosphere of the house which belonged to a priest who is now dead). There are further images within the story which support this claim. The beginning words of the first paragraph (North Richmond Street, being blind...) reflect the boy's relationship to reality which is blind. Actually the real North Richmond Street was blind, however this has also symbolic significance within the story. He uses this blind (dead-end) street as a symbol for the boys who are playing within it as aimless activity. The playing boys themselves stand for the Irish people who are uselessly struggling in the wrong and dead-ended way.

Almost all of the stories of Dubliners contain the element of epiphany. Epiphany according to James Joyce is a sudden spiritual manifestation in which the whatness of a common object or gesture appears visible to the observer. At the end of "Araby" an epiphany occurs and this is one of the famous examples of epiphanies in Joyce's works which is dramatic. While the boy was blind at the beginning, at the end he sees. The "blind" inexperienced narrator becomes, after his visit to the assumed "splendid" bazaar and his return to home, a completely different person: a learned person who is conscious of the devastating situation of Ireland under the domination of British rule.

In the second paragraph, there have been mentioned three books in their house which was formerly a dead priest's house. These include: The Abbot, The Devout Communicant and The Memoirs of Vidocq. Then the narrator without paying any attention to its content, prefers Memoirs of Vidocq, the one that has yellow color simply because of its color which seems conspicuous in the drab atmosphere of Dublin ("I liked the last best because its leaves were yellow"). The Abbot is a historical novel by Sir Walter Scott (1771-1832); like the narrator of "Araby", Roland Graeme who is its central character, is a young man reared by his relatives. And like the narrator of "Araby" who dreams of meeting Mangan's sister and then have a knightly quest to the splendid bazaar in order to buy a gift for his fair lady, Roland Graeme gets involved in romance and adventure. The Devout Communicant, or Pious Meditations and Aspirations for the Three Days Before and Three Days After Receiving the Holy Eucharist is the full title of the second book and is a catholic religious manual which was written by Pacificus Baker (1695-1774) an English Franciscan priest. Mentioning of this book indicates that Joyce sublimates the narrator's love towards Mangan's sister to the level of religious love and this anticipates his quest to the splendid bazaar. The third book was by Eugene Vidocq (1775-1857), a private detective, soldier, thief and a duelist. Mentioning of this yellow-covered book on the desk of priest suggests that even the priest had become depressed with the severity of religious life and drabness of Dublin's life and had kept reading it in order to escape such a life.

"The career of our play brought us through the dark muddy lanes behind the houses, where we ran the gantlet of the rough tribes from the cottages, to the back doors of the dark dripping gardens where odours arose from the ashpits" (third paragraph). The dark muddy lanes, and the dark dripping gardens and ashpits all represent the sort of disgusting life under the British rule.

"an uninhabited house of two storeys stood at the blind end, detached from its neighbours in a square ground" (Second paragraph). The kind of house drawn here though is real, perhaps also represents the kind of life within Dublin which is going nowhere. The kind of house which is isolated represents their limitation and lack of freedom for growth and advance while being under the British rule.

"I held a florin tightly in my hand as I strode down Buckingham Street towards the station" (twenty fourth paragraph). Florin was a silver coin that is now obsolete and worth two shillings. It had the picture of Queen Victoria on one side and for Irish people it was the reminiscent of the domination of the British rule. Also holding it tightly in his hand, the narrator implies the economic poverty imposed on them from the part of British rulers as a result of their domination.

As mentioned before, the narrator himself represents the dominated Ireland and Mangan's sister over whom he had no control, represents the British rule and domination over Ireland.

We know the girl through the name of "Mangan's sister". Clarence Mangan was the name of a poet who was Joyce's favorite and also was a poet to whom W. B. Yeats and Lionel Johnson payed considerable attention. In his poetries there can be seen some poems on Irish nationalism. He calls the girl who, as mentioned before stands for the colonizer, as Mangan's sister. Perhaps to show that the British rule is so much prevalent that has presence within the very warp of not only Ireland but also within Irish people and culture. 


\section{Conclusion}

From the post-colonial reading of "Araby" this essay concludes that besides many themes that Joyce wanted to portray through writing "Araby" ( the richest among all stories of Dubliners in terms of incorporating the majority of the themes of all of its short stories) he wanted to show the colonized nation of Ireland by the British Empire through the narrative voice of the story which is first person narration and also through the rich imagery and symbolism of the story, the conversation among the characters, naming of the characters and the description of the setting and atmosphere that is simultaneously realistic and symbolic.

In "Araby", Joyce through a realistic and lucid style of writing shows how the domination of the British ruling has been so intertwined within the Irish culture and he also portrays the entrapment of Irish people by this domination from which there seems to be no way out.

Joyce shows that although his language has been influenced by the colonization power of British Empire, still he is able to portray his critique of the ruling power and to portray the living status of Irish people through this language. As the most significant colonizing tool for colonizers, language has been turned against the workings of the colonizing power structures as a critical tool.

Dubliners is a collection of short stories which portray the growth from childhood into adolescence (bildungsroman). "Araby" as the last of the first phase (childhood) begins with a "blind" narrator who after the "quest" in order to gain the Holy Grail in the splendid bazaar for his fair lady, undergoes an epiphany: the realization of the drabness of Dublin living under the domination of the British Empire. "Araby" with its rich imagery and symbolism provided a strong reason for this essay to read it post-colonially.

\section{References}

Attridge, D. (2004). The Cambridge Companion to James Joyce. Cambridge: Cambridge University Press.

Barry, P. (2009). An Introduction to Literary and Cultural Theory. Oxford: Manchester University Press.

Bhabha, H. K. (1994). The Location of Culture. London: Routledge Press.

Boehmer, E. (1995). Colonial and Postcolonial Literature. New York: Oxford University Press.

Baldick, C. (2001). The Concise Oxford Dictionary of Literary Terms. New York: Oxford University Press.

Bowen, Z. R. (1995). Bloom's Old Sweet Song: Essays on Joyce and Music Florida James Joyce Series. Florida: University Press of Florida.

Childs, P. (1995). An Introduction to Post-Colonial Theory. London: Routledge.

Ellmann, R. (1975). Selected Letters of James Joyce. London: Faber and Faber.

Fargnoli, N \& Gillespie, M. P. (2006). Critical Companion to James Joyce. New York: Facts on File.

Hamadi, L. (2014). Edward Said: The Postcolonial Theory and the Literature of Decolonization. European Scientific Journal. Vol. 2 (1), Pp. 39-46.

Holquist, M. (1981). The Dialogic Imagination; Four Essays by Mikhail Bakhtin (C. Emerson \& M. Holquist). Texas: University of Texas Press.

Loomba, A. (2003). Colonialism/Postcolonialism. New York: Routledge.

Mahon, P. (2009). Joyce; A Guide for the Perplexed. London: Bloomsbury Academic.

Paulin, T. (1983). A new look at the language question. Belfast: Field Day Theatre Company.

Said, E. (2003). Orientalism. London: Penguin.

Söderkvist, P. (2013). James Joyce's Dubliners as Migrant Writing: A Vision of Ireland from Exile (Doctoral Dissertation). University of Stockholm.

Young, R. J. C. (2003). Postcolonialism; a Very Short Introduction. New York: Oxford Press. 